КОМПЕТЕНТНІСНИЙ ПІДХІД ЯК МЕТОДОЛОГІЧНА ОСНОВА ДОСЛІДЖЕННЯ ПРОФЕСІЙНОї КОМПЕТЕНТНОСТІ ОСОБИСТОСТІ

\title{
COMPETENCE APPROACH AS A METHODOLOGICAL BASIS FOR RESEARCH OF PROFESSIONAL PERSONALITY COMPETENCE
}

УДК 159.9-051-047.22

DOI https://doi.org/10.32843/2663-

5208.2020.16.38

\section{Мілорадова Н.Е.}

д.психол.н., доцент,

професор кафедри педагогіки

та психології

факультету № 3 (підготовка фрахівців для підрозділів поліції превентивної

діяльності)

Харківський національний університет

внутрішніх справ

\section{Шевченко В.В.}

аспірант кафедри соціології

та психології

Харківський національний університет внутрішніх справ у статті здійснено теоретичний аналіз компетентнісного підходу як методологічної основи дослідження профресійної компетентності особистості.

Науковий пошук спирався на використання теоретичних методів, а саме психологічного аналізу проблеми компетентнісного підходу як методологічної основи дослідження просресійної компетентності особистості, системного аналізу й узагальнення теоретико-методологічних підходів до питань, пов'язаних із компонентами профресійної компетентності й способами їі розвитку в майбутніх фрахівців.

У прочесі дослідження основна увага приділялася компетентнісному підходу як одному з головних методів, з допомогою якого можна сфрормувати та розвинути професійну компетентність. Виявлено, що професійна компетентність - че обізнаність фрахівця, знання й уміння та їх нормативні ознаки, що необхідні для виконання його професійної діяльності; володіння психологічними якостями, бажаними для ії здійснення, реальна просресійна діяльність відповідно до еталонів і норм. Просресійна компетентність формується та розвивається під час отримання фрахової освіти, саме тоді ж велика увага звертається на максимальне розкриття потенціалу кожної особистості, підготовлюючи ії до самовизначення, саморозвитку й самореалізації.

Компетентнісний підхід - це спрямованість освітнього процесу на формування та розвиток ключових і предметних компетентностей особистості, які вона буде використовувати під час професійної діяльності. Професійна компетентність належить до динамічних особистісних утворень, оскільки його змістове наповнення та якісний рівень залежать від багатьох чинників: рівня розвитку психології, педагогіки, антропології й культурології, соціальних та економічних умов. Ми впевнено можемо зазначити, що компетентність особистості стає інструментом реалізації власних можливостей $і$ досягнення профеесійно самореалізації. Головною вимогою сьогодення $\epsilon$ виховання інтелектуально-розвиненої та творчої особистості, яка є компетентною в різних сфрерах діяльності, зокрема профресійної.
Ключові слова: метод, пізнання, освіта, просресійна компетентність, компетент нісний підхід, особистість, фрахівець.

The article provides a theoretical analysis of the competency approach as a methodological basis for the study of professional competence of the individual.

The scientific research was based on the use of theoretical methods, namely psychological analysis of the problem of competence approach as a methodological basis for the study of professional competence, systematic analysis and generalization of theoretical and methodological approaches to issues related to the components of professional competence and ways to develop it in future professionals.

The research focused on the competency approach as one of the main methods by which you can form and develop professional competence. It is revealed that professional competence is the awareness of a specialist, knowledge and skills and their normative features that are necessary for the performance of his professional activity; possession of psychological qualities desirable for its implementation, real professional activity in accordance with standards and norms. Professional competence is formed and developed during professional education and at the same time much attention is paid to the maximum disclosure of the potential of each individual, preparing him for self-determination, self-development and self-realization.

Competence approach is the focus of the educational process on the formation and development of key and subject competencies of the individual, which he will use in professional activities. Professional competence belongs to the dynamic personal formations, as its content and quality level depend on many factors: the level of development of psychology, pedagogy, anthropology and culturology, social and economic conditions. We can confidently say that the competence of the individual becomes a tool for realizing their own potential and achieving professional self-realization. The main requirement of today is the education of intellectually developed and creative personality, which is competent in various fields, including professional.

Key words: method, cognition, education, professional competence, competence approach, personality, specialist.
Постановка проблеми. Динамічні реалії сьогодення, соціальні та економічні трансформації вимагають змін у наявних підходах до якості освіти. Саме це зумовлює пошук і розроблення нових технологій в освіти та вихованні особистості на етапі фахової підготовки. Забезпечення ефективності оборони й захисту територіальної цілісності України та реаліза- ція запиту силових структур у компетентних, конкурентоспроможних і надійних фахівцях зумовила виникнення змін у підготовці військовослужбовців Національної гвардії України. На сучасному етапі розвитку суспільства особистісно зорієнтована парадигма освіти ставить нові вимоги до здійснення навчально-виховного процесу. Велика увага зосереджується на 
максимальному розкритті потенціалу кожної особистості, підготовлюючи її до самовизначення, саморозвитку та самореалізації.

Аналіз останніх досліджень і публікацій. Так, І. Зимня в дослідженнях звертає увагу на те, що у XXI столітті спрямованість, цілі та зміст освіти орієнтується на «вільний розвиток людини», самостійність, ініціативність, мобільність, творчість і конкурентоспроможність майбутнього фахівця [1, с. 36-37].

Тому сучасний військовослужбовець - це передусім фахівець, професійнакомпетентність якого повинна бути переконливою та достатньою. Отримані професійні знання, сформовані професійно-важливі якості й уміння, бачення перспективи саморозгортання в професійному полі є основою його професіоналізму.

Аналіз напрацювань науковців сучасності свідчить про те, що вирішення питань набуття й розвитку основних груп компетентностей загального та фахового напряму, спрямованості освітнього процесу на досягнення високих результатів у навчанні є досить актуальним як зарубіжній, так і у вітчизняній науці.

Компетентнісний підхід визнаний базовою ідеєю реформування освіти в країнах Європейського Союзу й розглядається як стрижнева конструктивна ідея неперервної освіти впродовж життя [2, с. 67].

Дослідженням проблемних питань компетентнісного підходу в освіті займалися багато науковців сучасності, такі як Л. Анциферова, Г. Бал, В. Байденко, Н. Бібік, С. Вершловський, О. Дубасенюк, І. Зимня, І. Зязюн, Є. Клімов, В. Козирєв, Л. Любімов, М. Ларіонова, О. Міршук, В. Кушнір, В. Тихомиров, Л. Пуховська, Н. Радіонова, О. Реан, В. Сластьонін, О. Цільмак та ін.

Так, Н. Бібік досліджувала компетентності й компетенції в навчанні та початковій освіті; І. Бех розглядав компетентнісний підхід як освітню структуру; О. Дубасенюк вивчав формування професійної компетентності в майбутніх учителів; О. Міршук з'ясовував шляхи формування професійних компетентностей курсантів-психологів; О. Цільмак досліджувала застосування компетентнісного підходу під час підготовки фахівців правоохоронного профілю.

Аналіз робіт провідних науковців сучасності свідчить про значний інтерес до проблем формування та розвитку професійної компетентності в вищій освіті, застосування компетентнісного підходу у формуванні майбутніх професіоналів; характеристики компетентності в освіті зарубіжних країн, виникнення і становлення компетентнісного підходу.

Постановка завдання. На основі аналізу літературних джерел виокремимо й обґрунтуємо доцільність використання такого методологічного підходу, як компетентнісний, для розвитку професійної компетентності особистості.

Виклад основного матеріалу дослідження. Натепер однією з основних тенденцій розвитку сучасного суспільства $€$ підвищення вимог до якісних характеристик функціонування соціальних систем. Серед найважливіших із них є освітні системи, а саме система підготовки фахівців з вищою професійною освітою.

Сьогодні проблема підвищення якості освіти стала предметом багатьох зарубіжних і вітчизняних досліджень. На необхідності розвитку критеріїв і методології якості освіти вказано в більшості документів, які прийняті в рамках Болонського процесу, а також у Берлінському комюніке «Створюючи зону вищої освіти Європи» [3].

Погоджуємося $з$ думкою В. Журавського та М. Згуровського, що система вищої освіти в Україні має бути спрямована лише на її розвиток і набуття якісних ознак, глибоке осмислення, порівняння з європейськими критеріями і стандартами та визначення можливості їі вдосконалення на цьому етапі [4, с. 86].

Щоб вирішити проблему підвищення якості освіти, науковці почали пошук методологічних шляхів для вирішення цієї проблеми, одним із найпріоритетніших визнаний саме компетентнісний підхід, який основується на компетентностях і підкреслює практичний зв'язок сфери освіти зі сферою праці.

Визначення «компетентнісно зорієнтованої освіти» прийшло до нас із зарубіжних країн. Саме поняття «компетентнісна освіта» виникло в США в процесі вивчення досвіду роботи видатних учителів. Наприкінці 80-х на початку 90-х років здійснено спробу визначити компетентнісний підхід як такий, що орієнтує освіту на досягнення певного освітнього результату [5].

В американській теорії «компетентного працівника» найважливішим компонентом його кваліфікації є здатність швидко й безконфліктно пристосовуватися до умов праці. Тому головну роль у дослідженнях з питань розроблення компетентнісного підходу відіграє розроблення методів і способів підготовки компетентного працівника для певної галузі.

В українській системі вищої освіти протягом довгого часу панувала парадигма знань, основою якої $€$ те, що студенти вишів отримують фундаментальні знання, саме це було основою їхньої подальшої професійної діяльності. Але з кожним роком фахівців з вищою освітою більшає, а економіка нашої держави потерпає від нестачі професійних практично орієнтованих кадрів.

«Компетентнісний підхід» ми розуміємо як спрямованість освітнього процесу на формування та розвиток ключових і предметних ком- 
петентностей особистості, які вона буде використовувати під час професійної діяльності.

Компетентнісний підхід скеровує освітній процес на формування в здобувача освіти набору певних компетентностей, якими він повинен оволодіти під час отримання фахової освіти. Традиційна система освіти завжди акцентувала увагу на набуті знання, уміння та навичок, а компетентнісний підхід переміщує увагу з процесу накопичення визначених знань, умінь і навичок на формування й розвиток здатності практично діяти і творчо застосовувати набуті знання й досвід у різних ситуаціях.

Особливу увагу привертає точка зору Н. Нагорної, що саме компетентнісний підхід ставить на перше місце не поінформованість особистості, а вміння практично розв'язувати проблеми, які виникають у всіх сферах професійної діяльності та взаємодії [6, с. 267].

Компетентнісний підхід допомагає викладачеві зробити основним завданням зміщення/ перенесення акцентів інформаційної площини навчально-виховної діяльності на організаційно-методичну.

Ми розділяємо й думку В. Химинець, що перехід до компетентнісного підходу переорієнтовує освіту з процесу навчання на його результат. Цей підхід спрямовує увагу викладачів на організацію освітнього процесу на основі врахування потреби навчальних досягнень освітянина в суспільстві, забезпечує його спроможність відповідати реальним запитам динамічних змін ринку, а також загартовує його для швидкої безболісної адаптації в майбутній професії та соціальній структурі [7].

Натепер для реалізації компетентнісного підходу потрібно робити акцент як на міжнародний досвід, так і на наробки вітчизняних учених, з допомогою яких пізнається сутність компетентнісного підходу та його роль у сучасній освіті.

Щоб визначити сутність компетентнісного підходу, потрібно визначити й розмежувати поняття «компетентність» і «компетенція». У більшості словників поняття «компетенція» визначається як коло питань, у яких людина має знання й досвід, або те, у чому вона добре обізнана; це коло питань і завдань, які людина вповноважена вирішувати. Наведені вище визначення, на нашу думку, є загальними, але вони $€$ не зовсім точними: в одному випадку йдеться про досвід і знання, а в іншому абстрактне поняття «коло питань» [8, с. 346]. Також у науковій літературі компетенція (лат. competentia - належність за правом): коло повноважень будь-якого органу або посадової особи або коло питань, у яких ці особи володіють пізнанням і досвідом [9; 21]. Тобто із цих визначень ми можемо говорити про те, що компетенція включає сукупність взаємо- пов'язаних між собою якостей особистості, таких як знання, уміння, навички й способи, з допомогою яких вона виконує свою професійну діяльність. Саме ці особистісні якості задаються стосовно певного кола предметів і процесів, і саме вони є необхідними для того, щоб якісно, продуктивно та професійно виконувати діяльність.

Якщо звернутися до словників і наукової літератури щодо поняття «компетентність» (лат. competens - здібний), то це оволодіння компетенцією, інший варіант - це володіння знаннями, котрі дають змогу судити про будь-що [10, с. 84].

Термін «компетенція» дуже популярний у лінгвістиці, а також його широко застосовують під час викладання різних дисциплін. Саме Н. Холмський у 1965 році ввів його, а точніше, повернув у понятійний апарат лінгвістики. Але хотілося б зазначити, що цей термін і раніше зустрічався в роботах видатного мовознавця В. Гумбольта [11, с. 268; 12, с. 321]. Саме в працях він досліджував проблеми генеративної граматики й термін «компетенція» зазначався як здатність, яка необхідна для виконання мовленнєвої діяльності рідною мовою. Саме тому лінгвісти говорять про відповідну компетентність, що належить мовленнєвій особистості, тоді як психологи говорять про те, що компетентність $€$ психологічним новоутворенням особистості.

3 аналізу наукових досліджень ми бачимо, що в сучасній психології поступово встановлюються нові тлумачення понять «компетенція» та «компетентність». І. Соколова в працях зазначає, що «категорія компетентності $€$ наслідком нової економіки й сучасного підходу до людських ресурсів, тому що людині потрібно постійно адаптуватися до умов життя і праці, не є винятком й інноваційні технології» [13, с. 12]. Так, Дж. Равен уважає, що професійна компетентність - це розумові операції та практичні вміння [14, с. 72]. У свою чергу, А. Маркова наполягає на тому, що компетентність передбачає поєднання психологічних якостей особистості, 3 допомогою яких вона може діяти самостійно й відповідально [10, с. 84]. Науковець Ю. Фокін писав, що до елементів професійної компетентності варто зараховувати усвідомлені потреби та формування мотиву [15, с. 147]. О. Цільмак у дослідженнях акцентує увагу на тому, що є три компоненти професійної компетентності: особистісний, соціальний, діяльнісний, вониє взаємозалежними, взаємопов'язаними та детермінують розвиток один одного [16, с. 156].

Хотілося б відзначити й думку Т. Морозової, що компетентність $€$ індивідуальною характеристикою особистості, яка поєднує в собі психічні якості, психічні стани, які дають їй змогу діяти самостійно та відповідально під 
час виконання професійної діяльності. Оцінювання й вимірювання кінцевого результату праці є єдиним науковим способом судити про компетентність [17, с. 5].

Якщо розглядати компетентність у конкретній галузі, це буде поєднанням певних знань, здібностей і досвіду, які дадуть нам змогу обґрунтовано і змістовно судити про цю сферу, а також ефективно й професійно діяти в ній.

Отже, ми можемо говорити про те, що компетентність:

- $є$ невід'ємним компонентом структури особистості, саме в якому акумулюються ії життєвий досвід, який вона здобуває передусім під час отримання фахової освіти, потім у професійній діяльності й обов'язково під час взаємодії із соціальним оточенням;

- це відбиття професійного досвіду особистості в рамках компетенції конкретної професійної діяльності.

Високий рівень сформованої компетентності на певному етапі професійного розвитку поєднує в собі три види компетенцій, а саме: інтелектуальні (здібності до продуктивної аналітичної діяльності), соціальні (громадянська грамотність) та особистісні (здатність людини до спілкування, рефлексії, готовності до самоосвіти й підвищення професійного рівня впродовж усього життя).

Науковці та практики розвинених країн світу до питань удосконалення системи освіти з позиції компетентнісного підходу звернулися ще на початку 1990-х років. Причиною цього було становлення розвиненої демократії в цих країнах, а також становлення в них громадянського суспільства та розвинених ринкових відносин.

Експерти Ради Європи дотримуються тієї думки, що компетентності передбачають спроможність особистості відповідати на індивідуальні й соціальні потреби; комплекс ставлень, цінностей, знань, умінь і навичок [18].

Ми вважаємо, що компетентність не можна протиставляти вмінням або знанням. Це поняття є значно ширшим, і воно вже містить у собі «вміння» і «знання». Цю думку також підтвердив у дослідженнях М. Чошанов: компетентність виражає значення традиційної тріади «знання, уміння, навички», поєднуючи їх між собою, і визначається як поглиблене знання предмета або засвоєне вміння. Також із допомогою компетентності ми можемо описати реальний рівень підготовки фахівця, який здатний з-поміж декількох варіантів рішень обирати найбільш оптимальне, аргументувати й відхиляти хибні рішення, тобто володіти критичним мисленням. Компетентність передбачає постійне оновлення знань, оволодіння новою інформаціє, щоб успішно вирішувати свої професійні завдання в цей час, тобто компетентність є здатністю до актуального виконання діяльності. Компетентність складається зі змістового(знання) і процесуального (уміння) компонентів. Тобто мова йде про те, що компетентна людина повинна не тільки розуміти сутність проблеми, а й уміти іiї вирішувати практично. Залежно від ситуацій та обставин компетентний фахівець може використати конкретний метод вирішення проблем.

На основі саме цих тверджень М. Чошанов винайшов «формулу компетентності»: Компетентність = мобільність знань + гнучкість методу + критичність мислення [19, с. 18-19].

У дослідженнях ми підтримуємо А. Хуторського, який висвітив основні ідеї компетентнісного підходу, а саме:

по-перше, компетентність - це ключове поняття, оскільки воно поєднує в собі інтелектуальний і навиковий складники освіти;

по-друге, уже в саме поняття «компетентність» закладено ідеологію інтерпретації змісту освіти, сформованого від результату («стандарт на виході»);

по-третє, ключова компетентність є інтегративною за природою, так як вона містить низку однорідних або близьких знань і вмінь, які належать до широких сфер культури та діяльності.

Цей підхід не є новим, оскільки орієнтація на засвоєння вмінь, способів діяльності й узагальнених способів діяльності існувала як напрям розвитку психологічних досліджень і практики, однак не була провідною. Також А. Хуторський уважав, що формування певної компетенції досягається засобами освіти, культури, саме тому він розтлумачив термін «освітня компетенція» як сукупність змістових орієнтацій, знань, умінь, навичок і досвіду особистості щодо певного кола об'єктів реальної дійсності, необхідних для виконання нею соціально значущої продуктивної діяльності [20, с. 61].

В умовах вищої фахової освіти на особливу увагу заслуговує набуття майбутнім спеціалістом професійної компетентності, адже саме професійна компетентність є ключовою компетентністю, за допомогою якої фахівець буде виконувати свою професійну діяльність на високому рівні. Професійна компетентність як поєднання теоретичної та практичної готовності фахівця до виконання професійної функції характеризує не тільки його діяльність, а й самого фахівця як суб'єкта в його самостійній, відповідальній та ініціативній взаємодії із соціальним світом. Професійна компетентність інтегрує професійні й особистісні якості людини, спрямовує їх на опанування знань і практичних навичок, а також цілеспрямоване застосування цих знань і навичок у прогнозуванні, плануванні й реалізації професійної 
діяльності, активізує фахівця для розвитку особистісних здібностей, прагнення до самореалізації в професійній діяльності вже в період навчання в закладі вищої освіти.

Висновки 3 проведеного дослідження. Отже, ураховуючи вищезазначене, ми можемо говорити, що професійна компетентність належить до динамічних особистісних утворень, оскільки його змістове наповнення та якісний рівень залежать від багатьох чинників: рівня розвитку психології, педагогіки, антропології й культурології, соціальних та економічних умов. Сьогодні суспільство, яке все більше цінує інтелектуальний і творчий потенціал особистості, вимагає від людини компетентності в різних сферах діяльності, зокрема професійної. Ми впевнено можемо зазначити, що компетентність особистості стає інструментом, за допомогою якого вона будує власне життя, реалізує можливості і стає справжнім фахівцем у професійній діяльності. І робимо акцент на тому, що саме навчальний заклад повинен створювати всі умови для оволодіння здобувачами технологіями життетворчості, розкриття потенціалу самопізнання, самоактуалізації, саморегуляції, інтеграції в соціокультурний простір, адже саме компетентнісний підхід, на відміну від традиційного підходу до засвоєння готових наукових знань та алгоритмів конкретних видів діяльності, зорієнтований на розвиток суб'єкта й пов'язаний із культурою мислення, аналітичною рефлексією, самостійністю й відповідальністю людини за прийняття рішень у діалектичній єдності з духовно-моральними та ціннісними настановами особистості, незалежними від сфери й галузі їх застосування.

Упровадження компетентнісного підходу в систему освіти дає нам змогу значною мірою реалізувати особистісно-орієнтований, діяльнісний і практико-зорієнтований підходи в навчально-виховному процесі, оскільки виділення компетентностей у змісті навчальних дисциплін визначає орієнтири у відборі тих знань і навичок, які є найбільш значимими для формування ціннісних орієнтацій і які будуть реалізовуватися в житті особистості. Тому цей підхід можна розглядати як важливий інструмент розвантаження змісту, відбору відповідних знань і вмінь.

Перспектива подальших досліджень полягає в продовженні наукових розвідок у методології організації процесу цілеспрямованого розвитку професійної компетентності майбутніх військовослужбовців Національної гвардії України на етапі фахової підготовки.

\section{ЛІТЕРАТУРА:}

1. Зимняя И.А. Ключевые компетенции - новая парадигма результата современного образования. Высшее образование сегодня. 2003. № 5. С. 34-42.
2. Пометун О. Компетентнісний підхід - найважливіший орієнтир розвитку сучасної освіти. Рідна школа. 2005. № 1 (900). С. 65-70.

3. Комюніке конфреренції міністрів вищої освіти Європи. URL: https://zakon.rada.gov.ua/laws/ show/994_754\#Text (дата звернення: 02.06.2020).

4. Журавський В.С. Болонський процес : головні принципи входження в Європейський простір вищої освіти. Київ : ІВЦ «Політехніка», 2003. 200 с.

5. Карпова Л.Г. Формування професійної компетентності вчителя загальноосвітньої школи : дис. ... канд. пед. наук : 13.00.04. Харків, 2003. 167 с.

6. Нагорна Н.В. Формування у студентів понять компетентності й компетенції. Виховання і культура. 2007. № 1-2 (11-12). С. 266-268.

7. Химинець В. Компетентнісний підхід до професійного розвитку вчителя / Закарпатський інститут післядипломної педагогічної освіти. URL: http: zakippo.org.ua/2010-01-18-13-44-15/233-2010-08-2507-10-49 (дата звернення: 02.06.2020).

8. Сучасний тлумачний словник української мови. Харків, 2006. 832 с.

9. Словник UA. Портал української мови та культури. URL: https://slovnyk.ua (дата звернення: 02.06.2020).

10. Маркова А.К. Психологический анализ профессиональной компетентности. Советская педагогика. 1990. № 8. С. 82-88.

11. Гумбольдт В. Избранные труды по языкознанию. Москва, 1984. 397 с.

12. Гумбольдт В. Язык и фрилософрия культуры. Москва : Прогресс, 1985. 451 с.

13. Соколова І.П. професійна компетентність вчителя: проблема структури змісту. Неперервна профресійна освіта теорія і практика. 2004. № 1. С. 8-16.

14. Равен Дж. Компетентность в современном обществе: проблемы, заблуждения, перспективы. Москва : Когнито-центр, 2001. 142 с.

15. Фокин Ю.Г. Преподавание и воспитание в высшей школе. Москва : Прогресс, 2002. 224 с.

16. Цільмак О.М. Компетентнісний підхід під час підготовки фрахівців правоохоронного профрілю. Юридична психологія та педагогіка. 2009. № 2. C. 154-164. URL: file://C:/Users/admin/Downloads/ urpp_2009_2_17.pdf (дата звернення: 02.06.2020).

17. Морозова Т.Ю. Аналіз дефініцій компетентнісного підходу щодо освіти. Освіта Донбасу. 2005. № 3. C. 5-11.

18. Hutmacher Walo. Key competencies for Europe // Report of the Symposium. Berne, Switzezland 27-30 March, 1996. Council for Cultural Co-operation (CDCC) a // Secondary Education for Europe Strasburg, 1997.

19. Чошанов М.А. Дидактическое конструирование гибкой технологии обучения. Педагогика. 1997. № 2. C. 17-21.

20. Хуторский А.В. Ключевые компетентности как компоненты личностно-ориентированной парадигмы образования. Народное образование. 2003. № 2. C. 58-64.

21. Профрессиональное образование: словарь. Ключевые понятия, термины, актуальная лексика / главн. ред. С.М. Вишнякова. Москва : НМЦ СПО, 1999. $533 \mathrm{c}$. 